\title{
Comparison of integrative nature conservation in forest policy in Europe: a qualitative pilot study of institutional determinants
}

\author{
Tobias Schulz • Frank Krumm • Winfried Bücking • Georg Frank • \\ Daniel Kraus • Markus Lier • Marko Lovrić • \\ Marieke van der Maaten-Theunissen · Yoan Paillet • Jari Parviainen • \\ Giorgio Vacchiano - Kris Vandekerkhove
}

Received: 2 April 2014/Revised: 30 September 2014/ Accepted: 4 October 2014/

Published online: 15 October 2014

(C) Springer Science+Business Media Dordrecht 2014

\begin{abstract}
In this pilot study, we examine the relationship between the organisation of property rights and the economic importance of forestry on the one hand and the degree to which integrative nature conservation is formally implemented in forest policy on the other hand. Further, we are interested in whether political institutions moderate this relationship. We first offer a conceptualization of integrative nature conservation in forests and how to measure its implementation in law, ordinances and private agreements for a sample of European national and sub-national jurisdictions (Austria, Croatia, Finland, France, the Netherlands, Switzerland, Flanders, Baden-Württemberg and Piedmont). We subsequently try to assess the implementation of these rules and to relate them both to the structural characteristics of forestry and to an appraisal of pluralism in forest policy. Our qualitative analysis reveals that among the jurisdictions with a more centralized and corporatist forest policy, integrative nature conservation in forests tend to be less formally implemented the more corporatism dominates decision-making. It also confirms the expectation that among
\end{abstract}

Communicated by Georg Winkel.

T. Schulz $(\bowtie)$

Swiss Federal Research Institute for Forest, Snow and Landscape Research, Zürcherstrasse 111, 8903 Birmensdorf, Switzerland

e-mail: tobias.schulz@wsl.ch

F. Krumm · D. Kraus

EFI Central European Regional Office EFICENT, Wonnhalde 4, 79100 Freiburg, Germany

W. Bücking

Previously Forest Research Institute of Baden-Württemberg, Saalenbergstrasse 7, 79294 Sölden, Austria

G. Frank

Federal Research and Training Centre for Forests, Natural Hazards and Landscape, Hauptstrasse 7, 1140 Vienna, Austria

M. Lier · J. Parviainen

The Finnish Forest Research Institute, Yliopistokatu 6, PO Box 68, 80101 Joensuu, Finland 
the more consensual jurisdictions with a strong forestry sector, rules tend to be less formally implemented. Further, the suspicion prevails that in the latter case, such rules are either complemented with exceptions for private forests or higher compensation. A more in-depth comparative examination is needed to further corroborate these findings.

Keywords Integrative nature protection · Forest policy · Country comparison

\section{Introduction}

Nature conservation efforts, both in forests and elsewhere, primarily follow two different approaches (Kraus and Krumm 2013; Bollmann and Braunisch 2013): A segregative approach aims for a spatially explicit separation of areas for production and conservation, and focuses the efforts for biodiversity conservation in a network of strictly protected areas (e.g., IUCN conservation area categories I-III). The integrative approach to nature conservation on the other hand is relevant to multifunctional productive forests both within and outside protected areas where integration of productive and conservation goals (within the management unit) are possible and aimed for.

Although networks of strictly protected areas are further extended, and are essential for the conservation of many highly demanding species (e.g. Müller and Bütler 2010), a large majority of forests will continue to have a productive function. A multifunctional management, integrating nature conservation goals and production goals will therefore be essentially required to maintain large-scale biodiversity (Parviainen and Frank 2003). Accordingly, an adequate combination of segregative and integrative conservation strategies is needed to maintain ecosystem integrity, structural complexity and habitat connectivity (Bollmann and Braunisch 2013; Vandekerkhove et al. 2011; Kraus and Krumm 2013; Frank et al. 2007).

The effective implementation of corresponding biodiversity conservation rules (from common sense to law) into different forest policies has been identified as one of the main challenges of biodiversity conservation strategies in the future (Rands et al. 2010).

There is little knowledge, however, about how to identify integrative conservation strategies for forests and even less is known about the factors that support their implementation. Proceeding from this observation, we compiled information on state and private sector management rules that aim to secure biodiversity in forests as well as on the structure of forestry and the political organisation of forest policy in a set of European

M. Lovrić

European Forest Institute, Yliopistokatu 6, PO Box 68, 80101 Joensuu, Finland

M. van der Maaten-Theunissen

Institute of Botany and Landscape Ecology, University of Greifswald, Soldmannstrasse 15, 17487 Greifswald, Germany

Y. Paillet

Irstea, UR EFNO, Domaine des Barres, 45290 Nogent-Sur-Vernisson, France

G. Vacchiano

Università degi Studi di Torino, DISAFA, Via da Vinci 44, 10095 Grugliasco, Italy

K. Vandekerkhove

INBO, Research Institute for Nature and Forests, Kliniekstraat 25, Brussels, Belgium 
countries and sub-national jurisdictions (further called 'cases' or 'jurisdictions') in order to provide a preliminary contribution to the following research questions:

(1) How should integrative nature conservation be defined in terms of forest policy instruments that can be observed in different cases?

(2) Which institutional and structural characteristics of a case can explain the degree of formalization of integrative nature conservation instruments in forest policy?

This study constitutes a pilot approach aimed at developing the conceptual framework and provides a first insight on the possible drivers of implementation of biodiversityoriented forest policies in Europe. Starting point for our analysis was a number of reports on integrative nature conservation for different countries and sub-national jurisdictions that had been compiled within the framework of the INTEGRATE I project (see the list of reports preceding the reference list) and an additional questionnaire on specific indicators of integrative forest management (see below) sent to the respective authors

Building on this information, we will first conceptualize integrative nature conservation in forests. Based on our own expertise and previous published works, we then qualitatively assess the degree of formalization of conservation-oriented rules in forest policy and confront it to various possible economic and political determinants encompassing property rights structures and decision-making institutions.

\section{Materials and methods}

\section{Cases examined}

We a priori classified the cases of our sample in three groups that represent different models of decision-making (consensuality and centralisation) but also different structural characteristics of forestry in Europe (compare Winkel and Sotirov 2014 for a similar grouping):

Group A: Switzerland (CH), Baden-Württemberg (B-W) and Piedmont (Pie). These are jurisdictions with relatively consensual and decentralized decision-making institutions in general—but particularly for forest policy—and a relatively strong forest sector in which, however, public forests play a major role.

Group B: Finland (FI), France (FR), Croatia (HR) and Austria (AT). These are jurisdictions with a relatively centralized political system (except Austria) but particularly with centralized decision-making structures in forest policy, a strong private forest sector and a less consensual (and thus corporatist) organization of forest policy.

Group C: Netherlands (NL), and Flanders (Fla). These are jurisdictions with consensual decision-making institutions for forest policy and a forestry sector that is of lesser economic importance.

Conceptual background for measurement and analysis

\section{Integrative nature conservation in forest policy}

According to Jordan and Lenschow (2010), environmental policy integration aims at systematically connecting environmental policy goals with-sometimes conflictingsocial and economic considerations. What counts in the end is whether policy integration takes place at the instrument level (Jordan and Lenschow 2010). For example, by designing 
forest management rules for commercial forestry that shall secure biodiversity conservation and that are either mandatory or at least accepted by most actors in the sector.

However, negotiating and implementing policy integration requires procedural and organizational reforms (Sgobbi 2010). Ultimately, we thus aim at identifying the political institutions and the respective organization of political decision-making (e.g., national forest programmes) that support integrated nature conservation in forest policy.

\section{Indicators of integrative nature conservation in forests}

Integrative nature conservation in forests can be secured by designing and successfully implementing specific management instructions that provide a minimum habitat quality and conserve important (structural) elements for biodiversity (e.g., key habitats, habitat trees, dead wood) at the stand level. Forest management rules securing such integrative nature conservation in the productive forest are usually subsumed under labels such as "sustainable multifunctional forest management" or, more specifically, "close-to-nature" forestry. ${ }^{1}$

Several indicators for habitat quality and related "sustainable forest management" rules have been proposed (e.g. Secco et al. 2011a), but they are either too coarse for our purpose, or they lack focus on integrative nature conservation. Holvoet and Muys (2004) developed a comprehensive list of sustainable forest management regulations (including certification) for different administrative levels (national, international) in Europe. Similarly, Maes et al. (2011) provided a list of 157 potential indicators of the environmental aspects of sustainable forest management. However, this wealth of indicators can contain quite some overlap and redundancy (Hahn and Knoke 2010). Foster et al. (2010) provided a more manageable list of indicators that also included management concepts.

Based on Kraus and Krumm (2013), we propose five groups of indicators more specifically designed to identify integrative nature conservation management rules in forests at the stand level (see Table 2 in the results section for the individual indicators):

Forest stand structure: Restrictions on transformations from mixed or multi-layered stands to pure or mono-layered stands; limitations to understory treatments; preservation of traditional forest structures.

Tree species composition: Prescriptions about "natural" or native forest types and restrictions to their replacement with exotic species or about the allowed share of exotic species; prescriptions to fight invasive species in forests.

Old-growth stages and dead wood: Restrictions on felling old and habitat trees; retention of "old-growth patches"; retention of a minimum volume of dead wood.

Natural regeneration: Rules about natural regeneration of felled areas and treatment of areas that have experienced disturbances.

Target species/biotopes: Rules to preserve certain target species and special biotopes within forest stands (e.g., breeding sites, small habitats such as ponds); mapping of biodiversity spots and prescriptions on their treatment.

Other: Regulation of fertilization, gene sources, control of game population, seasonal harvesting bans, fixed skidding tracks.

Each of these thematic groups consists of 3-7 items, resulting in a list of 30 indicators (Table 2).

\footnotetext{
${ }^{1}$ We are aware that „close-to-nature“silviculture can be ill-defined and has been criticized for failing to emulate large-scale disturbances and therefore biodiversity associated to open landscapes (Puettmann et al. 2009).
} 


\section{Implementation of integrative nature conservation in forest policy}

Providing a list of indicators with relevant regulations in forest policy was not sufficient for our case, as we are also interested in how formalized and compulsory the respective rules are. McDermott et al. (2008, 2010) provided a corresponding instrument-typology for identifying the stringency of certification systems across countries. They differentiate between voluntary and mandatory instruments on the one hand and, on the other hand, between procedure-based instruments, requiring merely declarations of intents or plans, and behaviour-based instruments, providing specific prescriptions for forest management. This classification system is particularly helpful to identify the stringency of respective regulation since it allows to pin down the degree of compulsion as well as how ambitious the regulation is. We simplified this classification system by neglecting the ambition of the regulation — which would have been beyond the possibilities of this pilot study — and solely analyzing the degree of formalization, which is more or less congruent with the degree of compulsion employed by McDermott et al. (2008, 2010).

To assess the degree of formalization and legal compulsion, we identified first, similar as McDermott et al. (2008, 2010), whether a rule (a) is mandatory or (b) defines a voluntary state-led program. In addition, we examined in what sense the rule (c) is a formalized agreement of the private sector or between the public and the private sector and (d) whether or not financial incentives (subsidies) are provided to support participation or compliance with the rule. If no rule was in place, we looked for corresponding (e) "common-sense" practices that would be followed by forest managers and thus guide the management of a very large part of the forests (moral obligation). We addressed each indicator for private and public forests separately. In the process of examining criteria $a$ to $e$ for each case, we excluded commitments directly related to the EU Natura 2000 Directive as they apply more at a supra-national level than national. We then built an ordinal classification to describe the degree of implementation of biodiversity-oriented measures for each case (Table 1).

Table 2 in the results section was compiled based on a questionnaire that was distributed among the authors of this article. It contains the information about the formalization of integrative nature conservation regulation in different cases in a condensed form. While this table allows differentiating between the items of the above listed clusters of instruments, it aggregates the information about the type of instrument, compensation and common sense rules.

In the subsequent sections, we will formulate some expectations about how integrative nature conservation rules may depend on institutional determinants such as socio-economic structures of forestry and political system characteristics (institutions) of the forest policy sector of a jurisdiction.

\section{Structural and institutional determinants of conservation policies}

Overall, in a number of European countries integrative nature conservation has become an important issue on the political agenda. Concepts of "close-to-nature" forestry, and related management guidelines and instructions have been discussed in several countries for many years and substantial efforts have been undertaken to develop national forest programmes based on participatory processes (Schanz 2002; Rayner and Howlett 2007). However, in practice, a clear political consensus on integrative nature conservation does not arise in all European countries (Winkel and Sotirov 2014) and hence, the respective legislation may differ strongly, both, in formulation and in implementation. 
Table 1 Implementation of integrative nature conservation in forest policy

\begin{tabular}{ll}
\hline 0 & No regulation \\
1 & Common sense rules \\
2 & Non legally binding private sector agreement, low participation \\
3 & Non legally binding private sector agreement, high participation \\
4 & Legally binding but without mandatory participation and without compensation \\
5 & Legally binding but without mandatory participation and with compensation \\
6 & Legally binding and mandatory, without compensation \\
7 & Legally binding and mandatory, with compensation \\
\hline
\end{tabular}

Problem severity According to Konisky and Woods (2012), the willingness of the actors involved to tighten environmental regulation should increase with the severity of environmental degradation. One intuitively appealing explanation for why biodiversity conservation had been integrated into forest legislation and practice to differing degrees in different contexts is, of course, that the (perception of the) severity of the problem, i.e., biodiversity loss, differs across countries, due to various reasons.

It is difficult, however, to assess the degree of biodiversity loss comparatively by simply referring to official statistics, e.g. Forest Europe and UNECE/FAO (2011a), since suitable indicators are rare. Furthermore, measuring the state of biodiversity objectively does not tell about how the problem is perceived and how seriously it is considered by decisionmakers in the political sphere.

Socio-economic importance and structure of forestry Generally, the possibilities to impose strict regulation upon an industry diminish with the strength of the industries interestgroups (lobbies) in the political decision-making process. Lacking better alternatives, the strength of interest groups is often measured with the share of the Gross Domestic Product (GDP), the respective industry produces in the country (Konisky and Woods 2012).

More specifically however, Gulbrandsen (2008) provided an interesting comparative examination of the introduction of conservation instruments in forest policy (namely the amount of protected forests and the number of small reserves) for Norway and Sweden. Apart from features of the science-policy interface, he suggested two explanations that are relevant for the adoption of such rules:

(i) Extent of private ownership: Usually, relatively few forest owners have to bear the costs from nature conservation reforms in the forestry sector, while the benefits are usually distributed widely. Private forest owners, particularly if they are rather small family enterprises, often have reservations with respect to management restrictions for nature conservation even when offered compensation, not necessarily because of the extra cost but mainly because these constraints are perceived as imposed by state actors in a top-down manner and are thus regarded as inflexible (Pouta 2005; Serbruyns and Luyssaert 2006). As a consequence, due to the resistance and lobbying from the private forest sector, it seems difficult for countries and sub-national jurisdictions to successfully introduce binding rules about integrative nature conservation in forest law and ordinances if the private forest sector is economically important and effectively organized (Winkel and Sotirov 2011). A complementary argument is given by McDermott et al. (2010, p. 347), who hypothesize that the larger the share of public lands (in our case public forests) the stronger the pressure from civil 


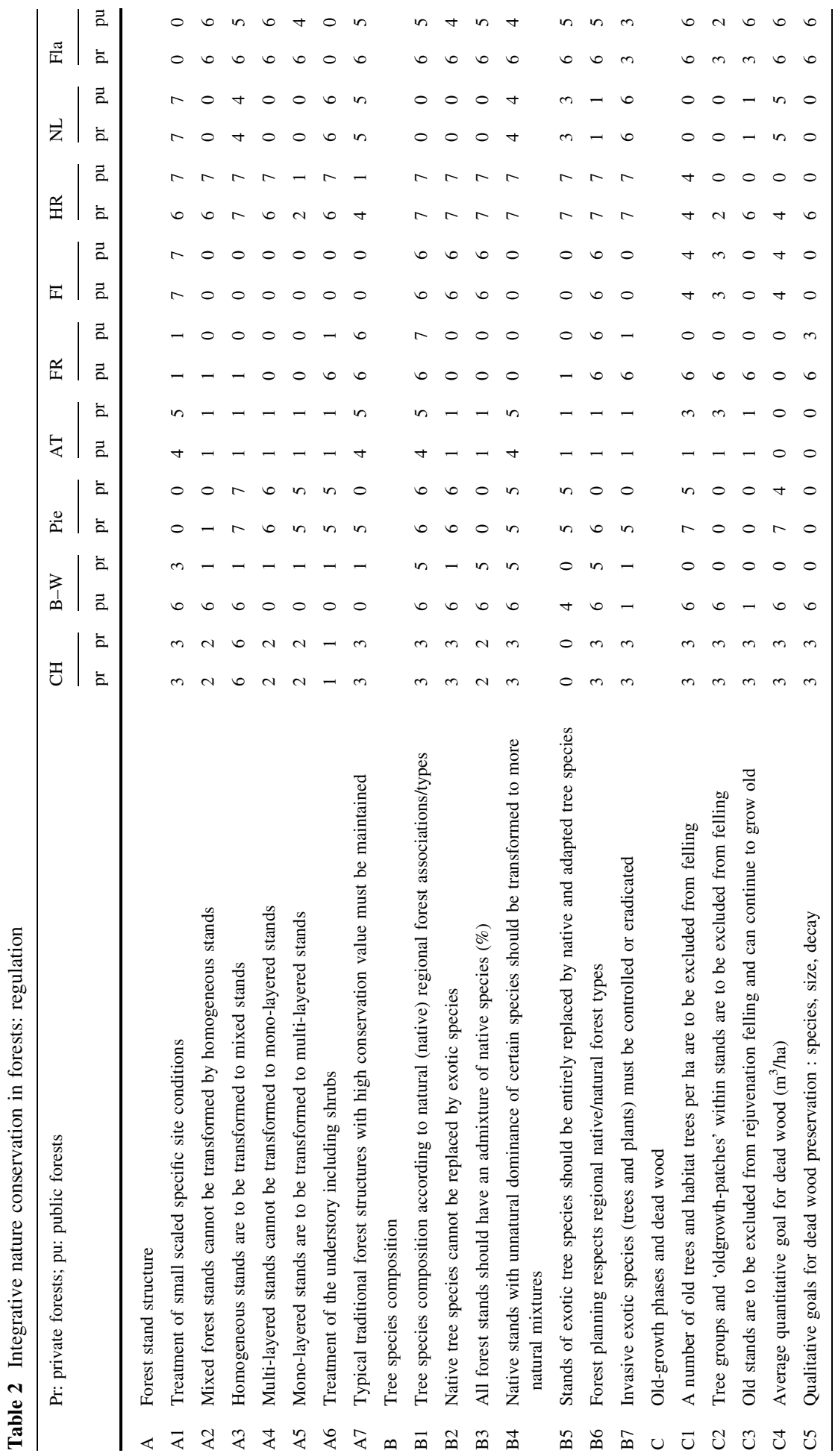




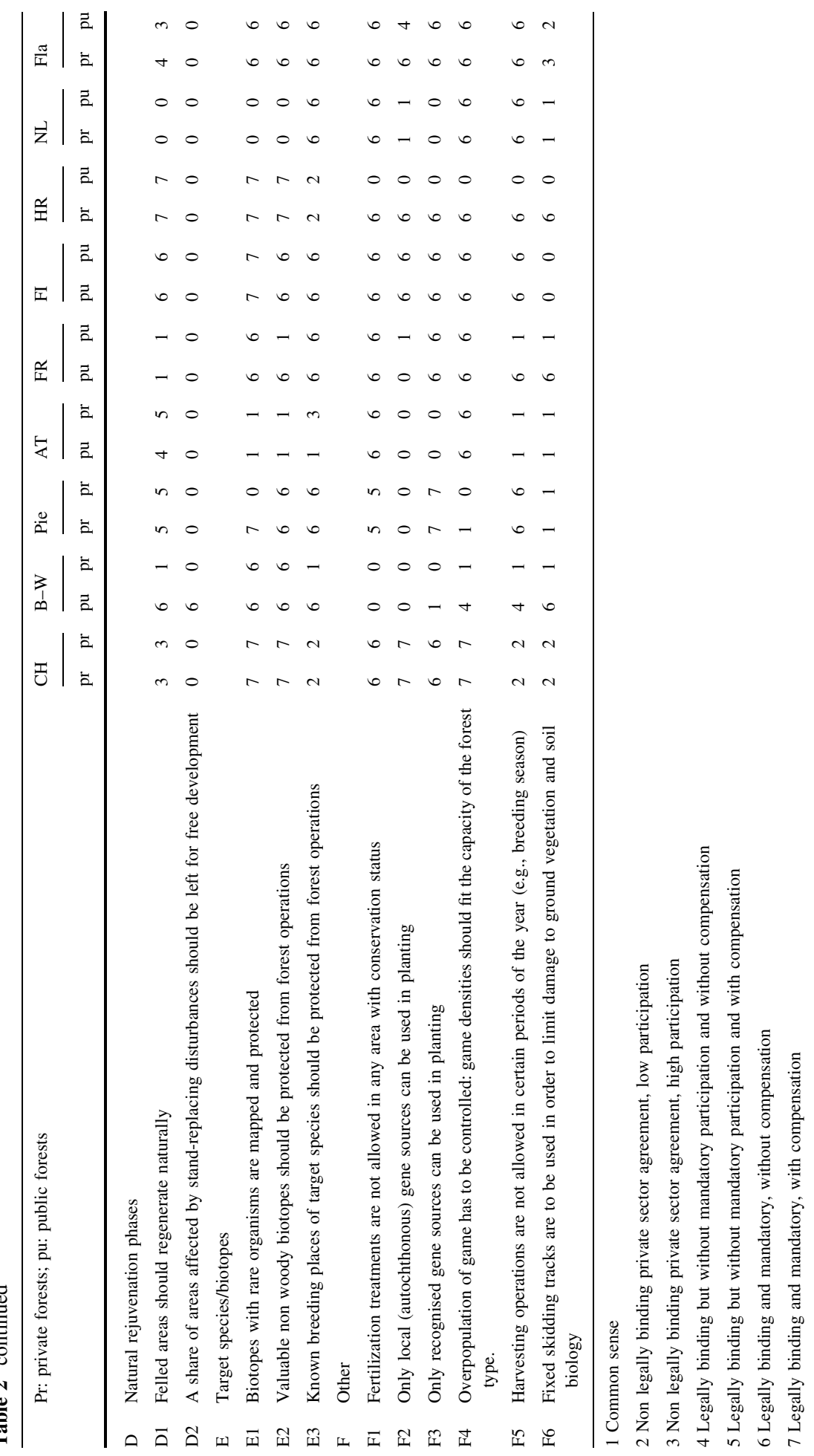


society and environmental organizations will be to tighten regulation (particularly concerning private actors).

(ii) Structure of private ownership: Furthermore, if forests are divided into small patches of private ownership, it is likely that a large share of a single owner's forest will be affected by conservation efforts towards local high conservation value scale (e.g., key habitats, biodiversity hotspots) that are unevenly distributed across a region's entire forest surface. This will impede implementation and, depending on how well the forestry sector is organised and how it acts as an interest group, either prevent the enactment of stricter rules or result in higher compensation for the management restrictions imposed.

Consensus orientation and decentralization in forest policy making Apart from those structural reasons, the broad political system characteristics, which differ remarkably between countries, might either facilitate or hinder the establishment of a set of formalized rules on integrative nature conservation. There is, however, not much scientific agreement about which kinds of decision-making structures support enacting stricter environmental policies. In a small sample of European countries, Poloni-Staudinger (2008) found that:

(i) on the one hand, countries with consensual political systems are more likely to adopt "command-and-control" instruments for environmental policy in general. On the other hand, she also showed that the more consensual a country, the less it will approve conservation policies. In her definition of consensuality, she refers to the first of Lijphart's (1999) dimensions of democracy, according to which consensual institutions secure a broader recognition of interests and their representation in political decision-making. However, she deliberately excludes one element: corporatist interest group organization, i.e., cooperative policy-making between a small number of peak interest organizations and the state. In Lijphart's (1999) conceptualization, corporatist interest group representation is actually an element of consensus democracies since this cooperative mode of decisionmaking results in some form of consensus between the involved actors. However, as Poloni-Staudinger (2008) argues, in the realm of environmental policy, the evidence on a positive impact of corporatism is mixed, as environmental interests are likely to be excluded in more narrowly defined corporatist decision-making processes affecting environmental policy. Hence, a consensual forest policy might be described as a policy-making approach that is open to various stakeholders and tries to integrate different opinions by providing formal venues for consultation or even co-decision opportunities. It certainly depends on the degree of consensus-orientation of the political system at large whether or not such venues are provided also in forest policy-making.

As conservation policies usually constrain the well organized interest groups, such as hunters associations and the agricultural sector, we expect that the latter will try to avoid respective management rules in a narrowly corporatist system. But even without narrow corporatism, consensual systems are still expected to "fail" in the conservation policy realm if economic interests are strong and are in conflict with conservationist's interests.

(ii) Federalism or decentralization, the second dimension adopted from Lijphart's (1999) democracy concept, supports the adoption of conservation policies. This is because at a regional level, it is assumed to be easier to come to adapted and acceptable solutions, even if well-organized interest groups will be negatively affected.

We thus expect less formalized rules for consensual (broad representation) system with a strong private forestry sector as well as for centralized and corporatist systems. If the private forestry sector is not that salient, consensuality might even be an asset for 
integrative nature conservation reforms in forest policy. More formalized rules can also be expected for decentralized systems.

Traditionally, forest policy had been organized in a corporatist manner in many countries. The degree of consensuality in forest policy is hard to assess, though. What could be observed, however, was a clear trend to elaborate National Forest Programmes (NFP) in European countries and this was also the case for virtually all the cases in our sample, albeit to differing degrees and starting at different points in time (Table 4). While the corresponding NFP-processes were mostly organized to secure the participation of various stakeholders and thus were meant to put national forest policy on more participatory and consensual grounds (Schanz 2002), this was not equally meaningful for all sampled cases.

Instead of counting participatory venues and official consultatory stakeholder organizations as a proxy of consensuality, we proceeded from a general assessment about how narrowly corporatist forest policy still was for our sample of jurisdictions and tried to judge whether or not a participatory NFP process was meaningful to possibly break up and reform closed decision-making structures in forest policy. If we judge this to be meaningful for a sample case, we try to assess to what extent the NFP was successful in doing so. This would then give a rough and indirect but nonetheless useful indication of consensuality of forest policy in that jurisdiction.

We have based our expertise on information about whether and when a NFP process was started, and if it was led by the forest administration or some other administrative unit, possibly the environmental protection agency. In the latter case, we would assume that decision-making in forest policy already follows a more consensual approach that allows the integration of nature conservation and forest production viewpoints. We also tried to assess whether a NFP was a truly iterative process and how the NFP influenced forest policy making in the country or sub-national jurisdiction, particularly by resulting in a policy document that was eventually endorsed by the government.

With respect to decentralization, an assessment of the degree of federalism in the political system in general is only of limited use in our context, because forest policy often follows its own procedures. We have evaluated, based also on information provided by the "qualitative indicators" reports of Forest Europe and UNECE/FAO (2011b), whether the authority to formulate policies was shared between the federal and the sub-national governments in a country, and which administrative level had the main responsibility for forest policy implementation and enforcement.

In the following sections, both the dependent and the independent variables are presented in rather crude ordinal and nominal scales. Based on a qualitative comparison, we assess the relative importance of different structural and political system characteristics on the degree of formalization of integrative nature conservation. We opted for a qualitative assessment as stricter interval scale measurement and would have been beyond the possibilities of this pilot study.

\section{Results}

Characterisation of the dependent variable: formalization of integrative nature conservation in forests

Table 3 preserves the differentiation between instruments, compensation and common sense rules but aggregates for the different dimensions of nature conservation in forests 


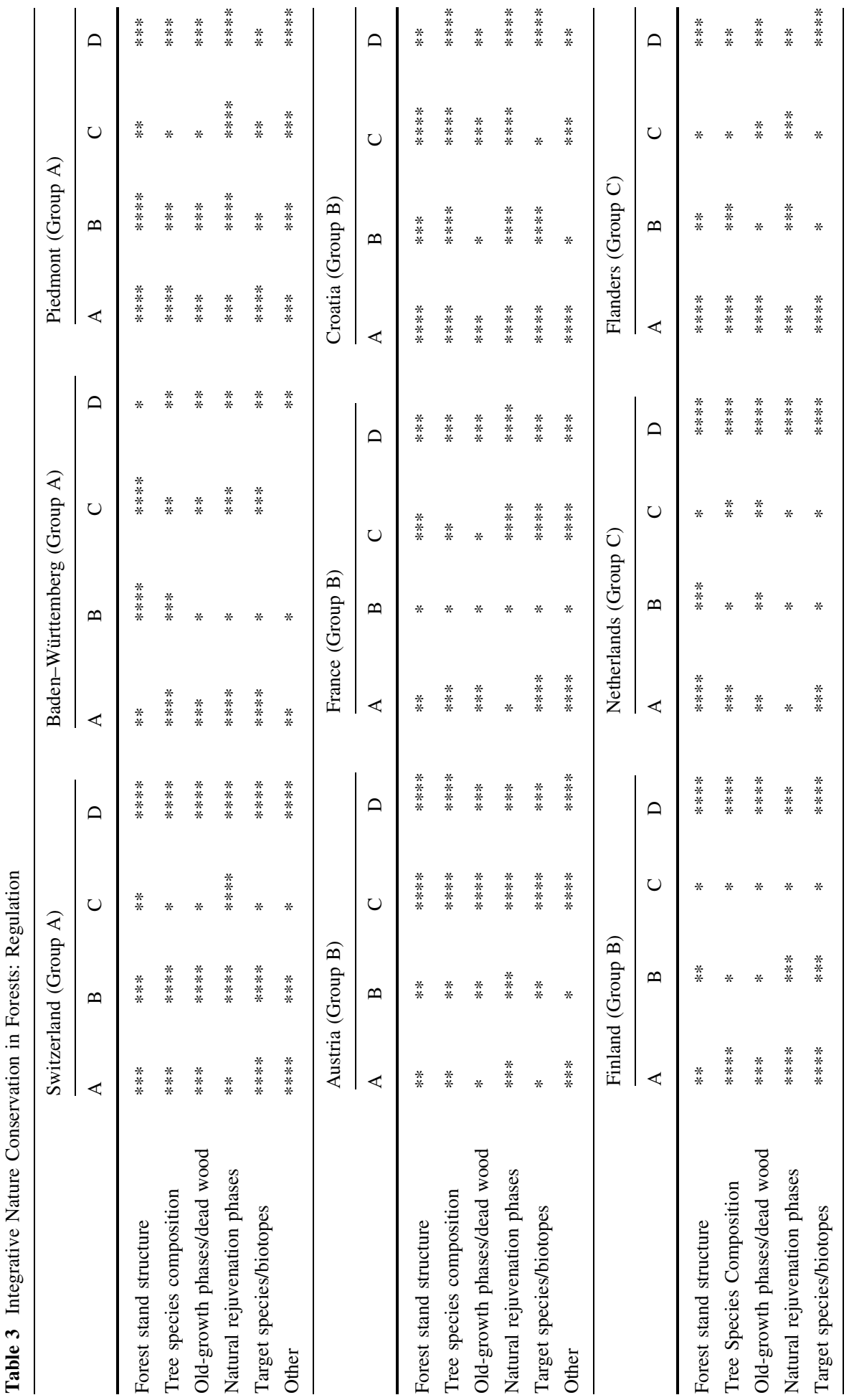




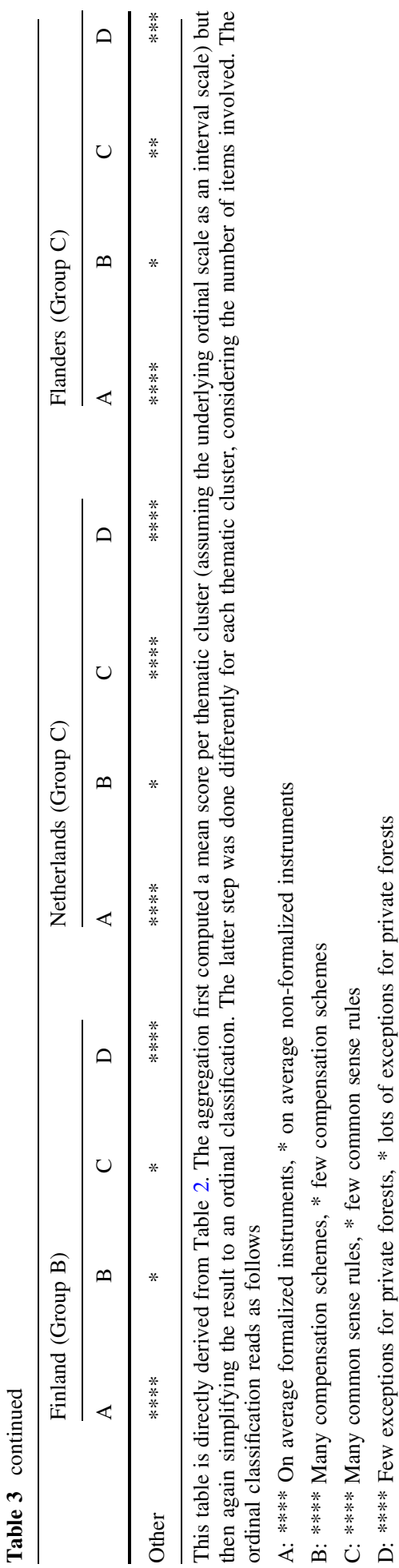


Table 4 Variables supporting qualitative judgements concerning the explanatory concepts employed (except problem severity)

\begin{tabular}{|c|c|c|c|c|c|c|c|c|c|}
\hline & $\mathrm{CH}$ & B-W & Pie & AT & FR & HR & FI & NL & Fla \\
\hline $\begin{array}{l}\text { Socio-economic characteristics of } \\
\text { forests }\end{array}$ & & & & & & & d & & \\
\hline $\begin{array}{l}\% \text { of total forest area owned by } \\
\text { private actors }\end{array}$ & 32 & 36 & 72 & 82 & 76 & 22 & 72 & 49 & 75 \\
\hline $\begin{array}{l}\% \text { of private forest area owned } \\
\text { by small private owners } \\
(<10 \text { ha })\end{array}$ & $70^{\mathrm{c}}$ & $70^{\mathrm{k}}$ & $(17)^{\mathrm{i}}$ & 11 & 35 & $97^{\mathrm{e}}$ & - & 42 & $\sim 70^{\mathrm{h}}$ \\
\hline $\begin{array}{l}\text { Average size of private } \\
\text { ownership in ha }\end{array}$ & 1.5 & 1.3 & $(5.7)^{\mathrm{i}}$ & 14 & 3.7 & $0.5^{\mathrm{f}}$ & 30 & 6 & 1 \\
\hline $\begin{array}{l}\% \text { of total forest area owned by } \\
\text { municipalities }\end{array}$ & 66 & $40^{1}$ & $(26)^{\mathrm{j}}$ & $3^{\mathrm{b}}$ & 14 & $0^{\mathrm{g}}$ & 2 & 13 & $10^{\mathrm{h}}$ \\
\hline $\begin{array}{l}\text { Forest area as per cent of total } \\
\text { area of jurisdiction }(\%)^{\mathrm{m}}\end{array}$ & 33 & 38 & 37 & 48 & 28 & 44 & 76 & 11 & 11 \\
\hline $\begin{array}{l}\text { Economic importance forestry } \\
\text { sector (ISIC/NACE 02): \% } \\
\text { GDP }^{\mathrm{m}}\end{array}$ & 0.1 & 0.2 & 0.3 & 0.5 & 0.2 & 0.4 & 2.2 & $<0.01$ & $<0.01$ \\
\hline $\begin{array}{l}+ \text { wood and paper products } \\
\text { (ISIC/NACE 02/20/21): \% } \\
\text { GDP }^{\mathrm{m}}\end{array}$ & 1.1 & & & 2 & 0.7 & 1.1 & 5.1 & 0.5 & \\
\hline $\begin{array}{l}\text { Decentralisation of national forest } \\
\text { policy }^{\mathrm{n}}\end{array}$ & + & + & 0 & $+^{o}$ & - & - & - & ++ & ++ \\
\hline Decision-making authority & Shared & Shared & Shared & Shared & Central & Central & Central & $\begin{array}{l}\text { Sub- } \\
\text { nat. }\end{array}$ & $\begin{array}{r}\text { Sub- } \\
\text { nat. }\end{array}$ \\
\hline Implementation responsibility & $\begin{array}{l}\text { Sub- } \\
\text { nat. }\end{array}$ & $\begin{array}{l}\text { Sub- } \\
\text { nat. }\end{array}$ & Shared & $\begin{array}{l}\text { Sub- } \\
\text { nat. }\end{array}$ & Shared & Central & Central & $\begin{array}{l}\text { Sub- } \\
\text { nat. }\end{array}$ & $\begin{array}{r}\text { Sub- } \\
\text { nat. }\end{array}$ \\
\hline \multicolumn{10}{|l|}{$\begin{array}{l}\text { Corporatism versus consensuality } \\
\text { in forest policy }\end{array}$} \\
\hline $\begin{array}{l}\text { Degree of corporatism in forest } \\
\text { policy }\end{array}$ & - & + & + & ++ & + & ++ & + & - & - \\
\hline $\begin{array}{l}\text { Degree of conflictive decision- } \\
\text { making }\end{array}$ & - & 0 & - & - & ++ & + & 0 & - & - \\
\hline $\begin{array}{l}\text { Broad participatory venues } \\
\text { other than NFP? }\end{array}$ & + & 0 & - & - & - & - & + & + & + \\
\hline Characteristics of NFP process & $\mathrm{r}$ & $\mathrm{x}$ & w & $\mathrm{p}$ & $\mathrm{t}$ & u & $\mathrm{s}$ & $\mathrm{q}$ & $\mathrm{v}$ \\
\hline Start of NFP process (or similar) & 2001 & 1998 & (2008) & 2003 & 2006 & 2002 & 1998 & 2004 & 1994 \\
\hline $\begin{array}{l}\text { NFP process led by forest } \\
\text { administration }\end{array}$ & No & Yes & (No) & Yes & Yes & Yes & Yes & No & Yes \\
\hline $\begin{array}{l}\text { NFP process influenced forest } \\
\text { policy-making }\end{array}$ & Yes & No & (Yes) & No & No & n.a. & Yes & No & No \\
\hline $\begin{array}{l}\text { NFP process led to revision of } \\
\text { forest law? }\end{array}$ & Yes & No & (No) & No & No & No & Yes & Yes & No \\
\hline $\begin{array}{l}\text { NFP established as an iterative } \\
\text { process }\end{array}$ & Yes & Yes & (Yes) & Yes & No & Yes & Yes & Yes & No \\
\hline Policy document available & Yes & Yes & (Yes) & Yes & Yes & Yes & Yes & Yes & Yes \\
\hline
\end{tabular}


Table 4 continued

\begin{tabular}{lllllllllll}
\hline & CH & B-W & Pie & AT & FR & HR & FI & NL & Fla \\
\hline Policy document endorsed by government & Yes & Yes & (Yes) & Yes & Yes & Yes & Yes & Yes & No \\
\hline
\end{tabular}

${ }^{a}$ If not otherwise indicated, figures are taken from UNECE/FAO, MCPFE and CEPF (2007). The ordinal scales in this table are 5-point scales running from "-" (very centralized/very weak degree) to " 0 " (shared/neutral) and "++" (very decentralized/very strong degree). At some places in the table a qualitative ordinal scale is implemented as the result of a qualitative assessment

b Weiss (1998)

c Brändli (2010, p. 254)

${ }^{\mathrm{d}}$ Finnish statistical yearbook of forestry (2013)

e Glück et al. (2011, p. 72)

f (Posavec et al. 2011, p. 110)

g Croatian Forests Ltd., 2006. Šumskogospodarska Osnova-Uređajni zapisnik (General forest management plan). Department for forest management, Directorate of Croatian Forests Ltd

${ }^{\text {h }}$ Vandekerkhove (2013); the figure for the \% of private forest area that are owned by small private owners $(<10$ ha) is an estimation since no reliable data is available

${ }^{\text {i }}$ There figures are only available at the national level: Italian National Institute of Statistics, census 2005; 2000, p. 104); figure for 1995: $11 \%$

${ }^{\mathrm{j}}$ FRA (2010, p. 11)

${ }^{k}$ Spielmann et al. (2013, p. 6)

${ }^{1}$ Spielmann et al. $(2013$, p. 6)

$\mathrm{m}$ For reasons of comparability, the figures are taken from Forest Europe and UNECE/FAO (2011b) and are valid for 2008, except for Piedmont (http://www.infc.it), Baden-Württemberg (Spielmann et al. 2013), Flanders (Vandekerkhove 2013). For France, figures from national statistics suggest that the forestry sector is economically more important (MAAPRATIFN 2011 and French National Institute for Statistic, 2005/pers. com. By A. Niedzwiedz). In Austria, due to scattered and disperse parcels of privately owned forests precise data are very difficult to survey. The official National Forest Inventory data show $53 \%$ forest properties smaller than 200 ha

${ }^{n}$ Apart from our own judgement, the information is taken from the reports of Forest Europe/UNECE/FAO as follows: AT: Prem (2010), BE: Laurent (2010), HRV: Gregurović (2010), FI: Veltheim (2010), FR: Chaudoron (2010), DE: Schmitz (2010), IT: Colletti (2010) and Venzi (2008), NL: Busink (2010), CH: Dürr (2010)

${ }^{\circ}$ Austria special case because forest policy is centralized and nature conservation decentralized

p Prem (2010) and Voitleithner (2004)

q Busink (2010) and Schanz and Ottitsch (2004)

${ }^{r}$ Dürr (2010) and Zimmermann and Zingerli (2004)

s Veltheim (2010) and Hänninen et al. (2004)

${ }^{t}$ Buttoud (2004) and Chaudron (2010)

" Contrary to what is indicated by Gregurović (2010), although a formal NFP process was planned in Croatia, it was never officially started. However, the government gathers forest experts and representatives from various stakeholder organisations for consultations on special issues concerning the forest law on a regular basis. Hence, there is kind of an iterative and participatory consultation process, although not officially a NFP process (Weiland 2012, Lovrić and Lovrić 2013)

${ }^{v}$ There is no national forest policy in Belgium as Forest policy is exclusively in the responsibility of the regions. On the national level, only an official consultation board exists (e.g., for formulation of national standpoints). For Flanders, the forest policy process is incorporated in the five-yearly 'environmental policy plan'. Within this framework 'forest action plans' can be formulated, incorporating specific forest policy goals. Legislative and policy initiatives are always submitted to an advisory board (MINA-council) representing all important stakeholders (land-owners, conservation NGO's,...). In this sense, the procedures are aimed at stakeholder participation and consultation. Flanders does not even have a specific explicit forest policy document because the policy is continuously and iteratively developed Lust et al. (2001, 2004)

w Only information on the National Forest Programme is available, because according to Cullotta and Maetzke (2008), Piedmont has never worked on a regional forest plan. We do not consider the first national Forest Plan from 1987 as a National Forest Programme document (Secco et al. 2011b; Colletti 2010; Carbone and Venzi 2004)

${ }^{x}$ According to Spielmann et al. (2013), the forest programme process in Baden-Württemberg was ceased before a final document could be approved. For the National Forest Programme of Germany, compare Schmitz (2010) and Elsasser and Pretzsch (2004) 
(forest stand structure, tree species composition, etc.). This allows judging whether formal instruments are accompanied by corresponding compensation schemes or whether they might be "substituted" by broadly obeyed common sense rules. We also included a column that lists whether or not private forest owners are given many exceptions from these rules. We refrained from computing an overall score for each case, though.

Among the cases of group A, integrative nature conservation seems to be least formalized in Switzerland. However, Switzerland is remarkably strong with the number of compensation schemes that have apparently been set up for many dimensions of integrative nature conservation (Angst 2012). Common sense rules are not particularly important. Most strikingly, however, private and public forests are mostly treated equivalent. There are some exceptions for private forests in Piedmont but otherwise, relatively numerous compensation schemes are supporting the rather high level of formalized integrative nature conservation rules. Although Baden-Württemberg has also established quite a number of formalized rules, it relies on quite some exceptions for private forests but it is lacking corresponding strength in compensation schemes.

Among the cases of group B, while we found many formalized instruments for Finland, this country is not particularly strong with respect to the number of compensation schemes, which could be identified only for natural rejuvenation and target species. Remarkably also, common sense rules are not so important and there are not many exceptions for private forests. France has somewhat less strictly formalized nature conservation rules, particularly also with respect to rejuvenation, and is particularly limited as far as compensation schemes are concerned. However, common sense rules seem to compensate at least less formalized regulation regarding rejuvenation and there are some exceptions for private forests. The latter aspect is not so different in Austria, although otherwise, the two countries seem to differ rather much: integrative nature conservation in Austria is not really formalized or subsidized but is embedded much more in common sense rules. In Croatia, due to the latest round of reforms in nature conservation laws (Weiland 2010), the formalization of nature conservation in forests is rather advanced, compensation schemes are well developed and so are common sense rules. However, quite some exceptions for private forests can be made out, particularly regarding forest stand structure and oldgrowth phases and deadwood.

As for the group $\mathrm{C}$, integrative nature conservation is not strongly formalized in the Netherlands, especially not regarding old-growth phases and rejuvenation. Compensation schemes are not very common and also common sense rules are not that widespread, although there exists a code of conduct provided by the forest owners' association, that is widely accepted and obeyed (Bosschap 2012). Flanders on the other hand, introduced particularly strongly formalized rules that are accompanied by some compensation schemes. Differentiation (or lower ambition levels) exists for private forests, though and common sense rules are not highly relevant.

\section{Measuring structural and institutional characteristics}

In the following section, we assess four potential explanatory characteristics of the jurisdictions under study. Most of the corresponding comparative information is collected in Table 4.

\section{Perceived problem severity}

In all cases under study, governments have taken up biodiversity issues on the political agenda, not at least due to some pressure by the UN Convention on Biological Diversity. A 
recent Eurobarometer Survey (Flash Eurobarometer 379 2013) revealed that "the decline and disappearance of forests" is perceived by 88-99 per cent of the surveyed as "very" to "fairly" serious problem in European countries.

Hence, what appears to differ more than the perception of the severity of the problem by the wider public, is the degree of conflict among stakeholders about possible remedies (Winkel and Sotirov 2011). Unfortunately, there are no comprehensive comparative assessments of stakeholder conflict across European countries available. We thus refrain from explicitly referring to problem severity but implicitly take this aspect into account with our assessment of consensuality in forest policy further below.

\section{Socio-economic importance and structure of forestry}

Obviously, ownership is one structural characteristic that is of outmost importance for our research question and it partly explains also saliency of forestry sector in the respective jurisdiction.

As listed in Table 4, in Switzerland and Baden-Württemberg (group A), private forests are rather small on average (only the national level average size is known for Italy/ Piedmont), but not extremely small as in some other cases and private ownership itself is not dominating except in Piedmont, which exhibits more than $70 \%$ of private forest. Particularly for Switzerland-and to a lesser extent also Baden-Württemberg-the high share of municipality forest has to be noted, while for Italy, municipality forests are not uncommon and we thus assume the share of municipality forest to be significant also in Piedmont. All three jurisdictions are otherwise rather similar, for example with respect to the size of the forest area and the relatively low share of the GDP the forestry sector is contributing.

Of group B, Austria, Finland and France exhibit more than $70 \%$ of private forest, while for Croatia this share is much lower (Table 4). In France, more than one-third of the private forests are smaller than 10 ha. Small-scale private forests are less common in Austria and Finland, though. France has also significant shares of municipality forest (Tissot and Kohler 2013), while we observed very small shares of municipality owned forests for Finland, Croatia, and Austria. In these latter countries, public forests tend to belong to the state or the provinces (Pulla et al. 2013). The forestry sector is reasonably large in all these countries except France. Finland clearly is the extreme end of the gradient in our sample with respect to the economic importance of the forestry sector (4\% of the GDP) and the size of the forest area (76\% of the country's surface area).

With respect to the structure of their forestry sector, Flanders and the Netherlands (group C) are quite different. In Flanders, the share of private forest lies above $70 \%$ and more than one third of the private forests are smaller than 10 ha, while in the Netherlands, on average, forest ownerships are larger and only about $50 \%$ of the forests are privately owned. For public forests, the share of community-owned forest is much lower in Flanders than in the Netherlands. However, what the two cases do have in common is a very low forest cover, in a highly populated and industrialized area, making the share of wood production to the GDP virtually negligible, and often subordinate to other functions (recreation, nature conservation).

\section{Decentralization of forest policy}

Our assessment of the degree of decentralization of forest policy is taken from various reports of Forest Europe/UNECE/FAO (as indicated in Table 4) together with our own 
judgement. Correspondingly, as can be read from Table 4, in Italy (Carbone and Venzi 2004; Venzi 2008), Switzerland (von Arb and Zimmermann 2004) and Germany, forest policy was decentralized, to a similar degree. We also found that similarly to their general political system, forest policy was more centralized in Finland, France and Croatia, although there are first attempts to organize forest policy in a more decentralized manner: in Finland, regional forest programs have been formulated since the late 1990s (Saarikoski et al. 2012) and in France, "forest territory charters", e.g., regional forest development programmes, have recently started (Buttoud et al. 2011). In Austria, while forest policy is somewhat but not entirely centralized, nature conservation policy is delegated to the subnational level, which causes problems of accountability with respect to biodiversity conservation in forests. Finally, decentralization was particularly strong in Belgium and the Netherlands.

\section{Consensuality in forest policy making}

For most of the jurisdictions in our sample, forest policy had been traditionally rather corporatist and therefore a NFP certainly made sense. However, not in many of our cases we could observe very successful NFP processes.

In Switzerland, Germany and Italy (group A), the forest sector was oriented towards sustainable timber production quite early and elements of corporatist decision-making still exist in the forest policies of these countries (Winkel and Sotirov 2011; Zingerli et al. 2004; Zimmermann and Zingerli 2004; Carbone and Venzi 2004). In Germany, a national forest programme process started early, proceeded as an iterative process and was improved over time in terms of the participative venues it provided (Elsasser and Pretzsch 2004). Nonetheless, it was not fully successful, as it did not resolve yet fundamental conflicts between timber production and nature conservation interests (Winkel and Sotirov 2011). Forest policy in Baden-Württemberg struggles with similar problems, although it was leading within Germany by providing the first regional forest programme process. This process was set up as a long-term commitment, but it had to be cancelled prematurely, again because of the conflict between forest production and nature conservation (Spielmann et al. 2013).

Similarly, in Switzerland, an extensive participatory effort resulted in a national forest programme that was, however, not endorsed by the government (at least not immediately) and did not result in a major revision of the forest law, as initially planned (Zingerli et al. 2004; Zimmermann and Zingerli 2004).

For Italy, the relatively positive assessment of the consensus-orientation of the national forest program process is owed to the "concertazione" approach that resulted in a relatively advanced participatory approach (Carbone and Venzi 2004; Secco et al. 2011b, p. 109ff). The integration of national agricultural and environmental policy and, as a consequence, of the corresponding branches of the national administration, is actually rather strong, although formally, environmental conservation and agriculture/forestry fall under the responsibility of different ministries. The forest sector is thus integrated into broader environmental planning processes, which is partly also due to its long-standing marginalisation (Carbone and Venzi 2004, p. 159; Colletti 2010). The degree of consensusorientation that has been detected at the national level cannot be confirmed for Piedmont as an Italian province, however. Here, forest policy decision-making processes are rather traditionally corporatist and not very participatory. Piedmont has been a laggard when it comes to the definition of a regional forest programme, and it seems that this is not going to change very soon (Cullotta and Maetzke 2008). 
For the cases of group B, it is also questionable whether the NFP processes had been very successful. According to Weiss (2004), Austria's forest policy institutions are known to be still narrowly corporatist. Nonetheless the national forest programme can be considered exemplary as it has probably started an iterative policy process that eventually might bear effects (compare Hogl 2000 for a similar argument). So far, however, he literature concludes that it has not (yet) led to a breakup of conventional modes of decision-making (Voitleithner 2004; Hogl et al. 2009).

In France, the situation is similar: traditionally, decision-making is top-down and conflictive, and the recent NFP, although prepared in a broad participatory process, is unlikely to change that very soon (Buttoud 2004). ${ }^{2}$ A notable exception is Finland, because it started its NFP process rather early (in the 1990s) by establishing it as an iterative process (Primmer 2011; Rantala 2008). Since then, the formerly highly corporatist structure of forest policy has been gradually altered and transformed into a more consensual policy-making process (Hänninen et al. 2004).

Croatia has started a policy dialogue with national stakeholders in 2002 with the assistance of the World Bank. Although guided by NFP principles, the only strategic document that it had produced was the National Forest Policy and Strategy from 2003 (Gregurović 2010), which was not followed by an implementation document, budgets or responsibilities and has no follow-up (Vuletic et al. 2008). However, the government gathers forest experts and representatives from various stakeholder organisations for consultations on special issues concerning the forest law on a regular basis. Hence, there is kind of an iterative process of participatory consultation, although not officially a NFP process. Since in Croatia, decision-making traditions are rather top-down and corporatist, the existing consultation is still merely informal and restricted to rather closed circles (Weiland 2012).

Flanders is probably the only case in our sample for which a National (or in that case Regional) Forest Programme was not very meaningful. A forest programme at the national level was not relevant, since forest policy authority is exclusively allocated to the regions. In Flanders, NFP-like policy documents were elaborated rather early (Lust et al. 2001). However, because a real NFP process would have established redundant decision-making structures and procedures to what existed already and because the existing institutions and consultation venues were functioning well in Flanders, there was little need for an explicit forest policy document, as its forest policy was already continuously and iteratively developed based on broad consultation (Lust et al. 2004).

The rather consensual organization of forest policy has different roots in the Netherlands, though: because the forests in the Netherlands are not geared towards timber production, forest policy had been "de-institutionalized" and "almost entirely" integrated into nature conservation policy (Veenman et al. 2009, p. 202). Hence a real NFP process never took place in the Netherlands. Rather, the Dutch Biodiversity Programme refers to forestrelated nature conservation issues and integrates also other forest-related policy documents produced since the end of the last decade (Busink 2010; van der Maaten-Theunissen and Schuck 2013).

\footnotetext{
${ }^{2}$ Participatory policy making is becoming more common in France, though. The "Grenelle de l'Environnement" that had been negotiated in 2008 under Sarkozy's presidency (2007-2012) had already brought together environmentalists and the forestry sector and resulted in the integration of biodiversity goals in management plans for pubic forest as well as corresponding committments by the owners of private forests. A participatory process is currently also applied to improve the reporting on Sustainable Forest Management indicators.
} 


\section{Discussion: determinants of integrative nature conservation in different jurisdictions}

Consensual decision making processes and a strong private forestry sector

The importance of public ownership and municipality forests in Switzerland has, according to Weiss (2004), prevented strong corporatist structures and facilitated the integration of competing objectives for forest policy during the last decades. To some extent, this is also true for Baden-Württemberg and hence, it would be mainly ownership structure as well as the comparatively lower importance of the forest sector that can explain the marginally more formalized integrative nature conservation policy in these two cases as compared for example to most cases of group B.

However, conflict with respect to integrative nature conservation remains in the group A jurisdictions. This is because the private and the public sector alike had always aimed at developing sustainable forest management. So far, forestry had thus not put too much pressure on biodiversity in forests and it hence is more difficult to convince forest owners about policy reforms that would prescribe something in a rigid bill rather than leave it as a rather implicit and therefore flexible norm of the private sector.

Comparing Switzerland with two sub-national entities is problematic with respect to decentralization. As von Arb and Zimmermann (2004) argue, though, a back and forth of competence delegation has helped to build a strong national forest policy that also takes into account nature conservation innovations from the sub-national jurisdictions in Switzerland.

From the comparison of the cases of group A (Switzerland, Baden-Württemberg and Piedmont), we can thus conclude that in these relatively consensual jurisdictions, a strong private forestry sector tends to prevent integrative nature conservation, as particularly compensation is less and exceptions for private actors are more common in BadenWürttemberg than in the two remaining jurisdictions with weaker forestry sectors. Switzerland, with its high shares of public and particularly municipality forests lacks exceptions for private forests while Piedmont, which has the weakest forestry sector in this group, rates relatively good on all four dimensions. ${ }^{3}$

Strong forestry sectors and rather corporatist decision-making

In Austria, private ownership is dominating the forestry structure, and the forests are rather large on average, which would suggest lower barriers to policy reforms. While in the mountain areas, common property forests are quite important (up to $40 \%$ of the forests), they are owned by agrarian associations, not the municipalities. State actors have thus less influence and forest owners are generally more reluctant to really engage in compromise seeking and to open up corporatist decision-making processes. Reforms end up to be more challenging due to corporatist decision-making institutions (Weiss 2004). In addition, since nature conservation and forest policy are not decentralized to similar degrees, it is much more difficult for nature conservation to be integrated into forest policy since this would require close cross-level coordination. Hence, policy reforms remain difficult, despite an

\footnotetext{
3 Italy has a strong tradition of limitations to the use of forests for public services (particularly regarding erosion control and landscape values, implemented by national laws, such as the Serpieri Forest Law of 1923 or the Glasso Law on Nature and Landscape of 1986) and this may also be a reason for the existence of a larger set of rules. While the Regional Forest Law of Piedmont does indeed list many mandatory limitations, they usually imply insufficient thresholds to really guarantee the conservation of biodiversity, and they have thus been strongly criticized by forest and environmental scientists alike.
} 
exemplary degree of participatory governance that was provided with the NFP-process (Quadt et al. 2013).

Similarly, in France, forest policy is still rather top-down and conflictive, despite more recent developments towards a more participatory bottom-up approach, while forests are largely in private hands and rather small on average. Hence, the hurdles for integrative nature conservation in forests are high. Instead, we observe exceptionally strong common sense rules in both countries which might compensate for the lacking formalization of integrative nature conservation rules.

In Croatia, the public enterprises are dominating the forestry sector. Thus, the apparently more formalized regulation with respect to integrative nature conservation is most probably less the result of a bottom-up participatory process and institutional reform but rather results from outside pressures (initiated by the accession to the EU) and from the political will in the government to comply. ${ }^{4}$ Although private forests in Croatia are extremely small on average, the share of private forests is not particularly large and hence the respective political reforms seem to be possible due to the strong top-down organization of the forestry sector. Still, the private forest owners receive quite some exceptions.

Earlier, Finland's structure of forest policy had been dominated by private forest owners and forest industry representatives. Since 1990, however, consensus seeking became more important an involved an increasing number of stakeholders. As a consequence, the biodiversity aspect was integrated into forest legislation over 15 years ago (Lier and Parviainen 2013). A new forest law entered into force at the beginning 2014. While the new law stipulates stricter requirements for biodiversity protection, the formulation of forest management methods is very low, the main principle being — as in earlier forest laws - that after regeneration cutting, the new forest should be created during a certain period depending on tree species and soil conditions. The freedom of forest owners to select the management alternatives in their own forests has thus widened. One reason for this revision was the insight that the preferences of the private forest owners are becoming more and more multifaceted. Formalization of integrative nature conservation is thus stronger in Finland than expected, notably also due to the Forest Biodiversity Programme for Southern Finland (METSO), which subsidizes voluntary forest protection contracts (10-20 years) between private forest owners and the state since 2008. Otherwise, however, financial incentives are not found in all domains of integrative nature conservation policies. Forest policy is thus rather consensual in Finland and under the assumption that conflict about the necessity to formalize corresponding forest management rules is not particularly strong, stronger formalization has not resulted in many exceptions for private forests.

It appears from the comparison o the cases of the group B (Austria, France, Croatia and Finland) that the more important the forestry sector is, the more it is dominated by private and well organized actors and the more these actors insist on centralized and corporative decision-making structures, the more difficult it is to implement integrative nature conservation as formalized and informal rules. The impact of the economic structure of private forestry is less obvious from this comparison: despite a smaller-scale forestry sector, integrative nature conservation is stronger in France (and compensation schemes nonetheless less common) than in Austria. Formalized conservation rules, compensation

\footnotetext{
${ }^{4}$ Clearly, these reforms are to some extent motivated by the planned accession of Croatia to the European Union, which has provided an extra momentum (Börzel and Buzogany 2010). A more comprehensive analysis would have to look also into the implementation of these rules, because it has been found that in transition countries, a high level of formal pre-accession compliance is usually followed by low level of practical compliance after the accession to the EU (Jacoby 1999, McDermott et al. 2010: 349).
} 
schemes and lacking exceptions also point to relatively strong integrative nature conservation in Croatia, although its private forests are very small on average. However, it would be prudent to observe these 'progressive' rules in the light of a decoupling of formal and practical integrative nature protection, which is a parallel to the decoupling of formal and practical compliance to international commitments in the case of Easter Europe's environmental governance (Jacoby 1999).

Consensus oriented systems with a relatively weak forestry sector

As far as group $\mathrm{C}$ of clearly consensus oriented and strongly decentralized jurisdictions with a weak forestry sector is concerned, the differences (stronger rules and more compensation but also more exceptions for private actors in Flanders) are difficult to explain solely with the information contained in Table 4.

The two jurisdictions seem very similar from a distance: in the Netherlands (Veenman et al. 2009) and Flanders (Vandekerkhove 2013) the forest administration is integrated into the environment and nature conservation sector of the public administration. In both regions, the local economy is not dependent on timber production and private owners whose main objective is wood production are a small minority (Van Herzele and Van Gossum 2009; Van Gossum and De Maeyer 2006). Although there is quite some mistrust towards government regulations (Serbruyns and Luyssaert 2006; Van Herzele and Aarts 2013), state programs for nature conservation are negotiated, sometimes adapted and eventually accepted, and hence the degree of conflict remains low (Vandekerkhove 2013). Under such circumstances, a tradition of consensual and participatory decision-making can be an asset for integrative nature conservation in forest policy.

However, all indicators of Table 4 that differ between these two cases suggest more formalized integrative nature conservation in the Netherlands, particularly the smaller private forestry sector with larger units on average. However, what also differs is that in Flanders the forest sector itself is already organized in a consensual manner. Hence, one might conclude that forest policy in Flanders had managed to incorporate nature conservation aspects rather early and to develop them in a continuously whereas in the Netherlands, it is rather the nature conservation sector that puts some pressure on forestry but with limited success.

\section{Limitations of the study}

Before we proceed to the conclusion, it is worthwhile to state three limitations of our pilot study: First, for our comparative analysis we have chosen jurisdictions that are vested with the main authority for forest policy and we have collected information about integrative nature conservation policies at the level of these jurisdictions exclusively. Ideally, we would be able to measure integrative nature conservation rules at all levels of government for all cases, but this was beyond our possibilities for this paper. Second, we have not examined the relative strength of integrative nature conservation policy but only its formalization. While it would be interesting to extend the research into this direction-taking McDermott et al. 2008 as an example - it is a significant complication for the comparative assessment. Lastly, our investigation into the consensuality of forest policy in different jurisdictions remains rather coarse and based on a literature review. Clearly, conceptualising and measuring consensuality in forest policy more explicitly would be an important next step. 


\section{Conclusions, implications for forest policy, and suggestions for further research}

This study was meant as a first attempt to provide a framework of analysis to compare the formalization of integrative nature conservation in forests and to gain some insights into possible determinants.

Not very surprisingly, our analysis confirms that more explicit regulation for integrative nature conservation in forests is less likely in cases with a strong and important forestry sector. The effect of the ownership structure (number of small forests) is less obvious, though. A strong forestry sector is more likely to oppose and hamper clearly formalized management rules and restrictions or to achieve compensation in consensual forest policy structure. If the forestry sector is weak though, consensuality rather seems to support formalized biodiversity conservation rules. However, specific case-specific circumstances may result in exceptions to this overall conclusion (e.g. succes of the METSO programme in Finland).

A next step in this research should not only be to extend the list of countries and subnational jurisdictions examined. It would also be useful to develop a method to comprehensively measure integrative nature conservation rules at all levels of government and to comparatively assess also the stringency of regulation as well as the amount of compensation, in order to allow more quantitative analyses. Our study has revealed that there is potential in inquiring into the effects of consensuality in forest policy. More systematic research would be needed, though, to explore whether consensual institutions can really support long-term reforms which might result in less conflictive policy making.

Acknowledgments France We are grateful to C. Biache (ONF, France), M. Gosselin (Irstea, France), S. Groualle (MAAF, France), P. Beaudesson (CNPF, France) for helping us filling the assessment tables and subsequent informative discussions on integration at a national level. Switzerland We are grateful to Kurt Bollmann (WSL) and Anton Bürgi (WSL) for giving valuable information about the organisation of nature conservation in Swiss forests.

\section{Country reports of the INTEGRATE I project}

Angst M (2012) Integration of nature protection in swiss forest POLICY. INTEGRATE country report. EFICENT-OEF, Freiburg

Van der Maaten-Theunissen M, Schuck A (2013) Integration of nature protection in forest policy in the Netherlands. INTEGRATE country report. EFICENT-OEF, Freiburg

Vandekerkhove K (2013) Integration of nature protection in forest policy in Flanders (Belgium). INTEGRATE country report. EFICENT-OEF, Freiburg

Lier M, Parviainen J (2013) Integration of nature protection in forest policy in Finland. INTEGRATE country report. EFICENT-OEF, Freiburg

Lovrić M, Lovrić N (2013) Integration of nature protection in Croatian forest policy. INTEGRATE country report for Croatia. European Forest Institute, EFICEEC - EFISEE Regional Office

Spielmann M, Bücking W, Quadt V, Krumm F (2013) Integration of nature protection in forest policy in Baden-Württemberg (Germany). INTEGRATE Country Report. EFICENT-OEF, Freiburg

Tissot W, Kohler Y (2013) Integration of nature protection in forest policy in France. INTEGRATE Country Report. EFICENT-OEF, Freiburg

Quadt V, van der Maaten-Theunissen M, Frank G. (2013) Integration of nature protection in Austrian forest policy. INTEGRATE country report for Austria. EFICENT-OEF, Freiburg

\section{References}

Bollmann K, Braunisch V (2013) To integrate or to segregate: balancing commodity production and biodiversity conservation in European forests. In: Kraus D, Krumm F (eds) Integrative approaches as an opportunity for the conservation of forest biodiversity, chapter 1.1, pp 18-31 
Börzel TA, Buzogany A (2010) Environmental organisations and the Europanisation of public policy in Central and Eastern Europe: the case of biodiversity governance. Environ Polit 19(5):708-735

Bosschap (2012) Gedragscode Bosbeheer 2010-2015. http://www.bosschap.nl/cmsAdmin/uploads/ gedragscode-bosbeheer-2010-2015.pdf. Accessed Mar 2014

Brändli UB (ed) (2010) Schweizerisches Landesforstinventar. Ergebnisse der dritten Erhebung 2004-2006, Birmensdorf: Eidgenössische Forschungsanstalt für Wald, Schnee und Landschaft WSL

Busink RL (2010) Reporting on the pan-European qualitative indicators for sustainable forest management and national implementation commitments of the ministerial conference on protection of forests in Europe: Netherlands, Tech. rep., UN economic commission for Europe, food and agricultural organization, ministerial conference on the protection of forests in Europe, Geneva

Buttoud G, Kouplevatskaya-Buttoud I, Slee B, Weiss G (2011) Barriers to institutional learning and innovations in the forest sector in Europe: markets, policies and stakeholders. For Policy Econ 13(2):124-131

Buttoud G (2004) France: A forests strategy with no programme? In: David Humphreys (ed) Forests for the future. National forest programmes in Europe. Country and regional reports from COST Action E19, pp 101-111

Carbone F, Venzi L (2004) Italy: The evolution of a 1980s national forest policy. In: David Humphreys (ed) Forests for the future. National forest programmes in Europe. Country and regional reports from COST Action E19, pp 159-175

Chaudron A (2010) Reporting on the pan-European qualitative indicators for sustainable forest management and national implementation commitments of the ministerial conference on protection of forests in Europe: France, Tech. rep., UN economic commission for Europe, food and agricultural organization, ministerial conference on the protection of forests in Europe, Geneva

Colletti L (2010) Reporting on the pan-European qualitative indicators for sustainable forest management and national implementation commitments of the ministerial conference on protection of forests in Europe: Italy, Tech. rep., UN economic commission for Europe, food and agricultural organization, ministerial conference on the protection of forests in Europe, Geneva

Cullotta S, Maetzke F (2008) La Pianificazione Forestale ai diversi Livelli in Italia. Italia Forestale e Montana 1:29-47

Dürr C (2010) Reporting on the pan-European qualitative indicators for sustainable forest management and national implementation commitments of the ministerial conference on protection of forests in Europe: Switzerland, Tech. rep., UN economic commission for Europe, food and agricultural organization, ministerial conference on the protection of forests in Europe, Geneva

Elsasser P, Pretzsch J (2004) Germany: A socio-political dialogue to promote sustainable forest management. In: David Humphreys (ed) Forests for the future. National forest programmes in Europe. Country and regional reports from COST Action E19, pp 113-126

Finnish Statistical Yearbook of Forestry (2013). Finnish Forest Research Institute (Metla). http://www. metla.fi/metinfo/tilasto/julkaisut/vsk/2013/index.html Accessed Mar 2014

Flash Eurobarometer 379 (2013) Attitudes towards Biodiversity. Report. European Commission, Directorate-General for Environment and Directorate-General for Communication

Forest Europe and UNECE/FAO (2011a) Forest Types. In: Forest Europe and UNECE/FAO (eds) The State of Europe's Forests. Status and trends in sustainable forest management in Europe, Geneva, http:// www.unece.org/forests/fr/outputs/soef2011.html. Accessed Mar 2014

Forest Europe and UNECE/FAO (2011b) Pan-European qualitative indicators for sustainable forest management. In: Forest Europe and UNECE/FAO (eds) The State of Europe's forests. status and trends in sustainable forest management in Europe, Geneva, http://www.unece.org/forests/fr/outputs/soef2011. html. Accessed Mar 2014

Foster BC, Wang D, Keeton WS, Ashton MS (2010) Implementing sustainable forest management using six concepts in an adaptive management framework. J Sustain For 29(1):79-108

FRA (2010) Country report Italy. Global forest resources assessment 2010, Nr. 101. Forestry department, food and agriculture organization of the United Nations, Rome

Frank G, Parviainen J, Latham J, Vandekerkhove K, Schuck A, Little D (2007) Main results, conclusions and recommendations. In: Frank Georg et al (eds) Protected forest areas in Europe-analysis and harmonisation (PROFOR): results, conclusions and recommendations. Federal research and training centre for forests. Natural Hazards and Landscape, Vienna, pp 149-159

Glück P, Avibegovic M, Cabaravdic A, Nonic D, Petrovic N, Posavec S, Stojanovska M (2011) Private forest owners in the Western Balkans-Ready for the formation of interest associations, research report 25, European Forest Institute 
Gregurović (2010) Reporting on the pan-European qualitative indicators for sustainable forest management and national implementation commitments of the ministerial conference on protection of forests in Europe: Croatia

Gulbrandsen LH (2008) The role of science in environmental governance: competing knowledge producers in Swedish and Norwegian forestry. Glob Environ Polit 8(2):99-122

Hahn WA, Knoke T (2010) Sustainable development and sustainable forestry: analogies, differences, and the role of flexibility. Eur J For Res 129(5):787-801

Hänninen H, Ollonqvist P, Saastamoinen O (2004) Finland: sustainable welfare via forest diversity. In: David Humphreys (ed) Forests for the future. National forest programmes in Europe. Country and regional reports from COST Action E19, pp 87-99

Hogl K (2000) The Austrian domestic forest policy community in change? Impacts of the globalisation and Europeanisation of forest politics. For Policy Econ 1:3-13

Hogl K, Nordbeck R, Kvarda E (2009) When international impulses hit home: the role of domestic policy subsystem configurations in explaining different types of sustainability strategies. For Policy Econ 11:357-364

Holvoet B, Muys B (2004) Sustainable forest management worldwide: a comparative assessment of standards. Int For Rev 6(2):99-122

Jacoby W (1999) Priest and penitent: the European Union as a force in the domestic politics of Eastern Europe. East Eur Const Rev 8(1-2):62-67

Jordan A, Lenschow A (2010) Environmental policy integration: a state of the art review. Environ Policy Gov 20:147-158

Konisky DM, Wood ND (2012) Measuring state environmental policy. Rev Policy Res 29(4):544-569

Kraus D, Krumm F (2013) Integrative approaches as an opportunity for the conservation of forest biodiversity. European Forest Institute, Freiburg

Laurent C (2010) Reporting on the pan-European qualitative indicators for sustainable forest management and national implementation commitments of the ministerial conference on protection of forests in Europe: Belgium. Tech. rep., UN economic commission for Europe, food and agricultural organization, ministerial conference on the protection of forests in Europe, Geneva

Lijphart A (1999) Patterns of democracy: government forms and performance in thirty-six countries. Yale University Press, New Haven

Lust N, Nachtergale L, Serbruyns I (2001) Long term plan forestry and action plan forestry in flanders. Silva Gandav 66:89-115

Lust N, Serbruyns I, Van Gossum P (2004) Flanders: a free-standing regional forest programme in Belgium. In: David Humphreys (ed) Forests for the future. National forest programmes in Europe. Country and regional reports from COST Action E19, pp 319-329

MAAPRAT-IFN-Indicateurs de gestion durable des forêts françaises métropolitaines. 2011

Maes WH, Fontaine M, Rongé K, Hermy M, Muys B (2011) A quantitative indicator framework for stand level evaluation and monitoring of environmentally sustainable forest management. Ecol Ind 11(2):468-479

McDermott CL, Noah E, Cashore B (2008) Differences that 'Matter'? A framework for comparing environmental certification standards and government policies. J Environ Plan Policy Manage 10(1):47-70

McDermott CL, Cashore B, Kanowski P (2010) Global environmental forest policies, London/New York: Earthscan

Parviainen J, Frank G (2003) Protected forests in Europe approaches-harmonising the definitions for international comparison and forest policy making. In: Parviainen, J (ed) Special issue: maintaining forest biodiversity. J Environ Manag 67(1): 27-36

Poloni-Staudinger LM (2008) Are consensus democracies more environmentally effective? Environ Polit 17(3):410-430

Posavec S, Šasěk M, Beljan K (2011) The structure and potential of small scale forests in the North-West of Croatia. In: FVA (ed.), Small scale forestry in a changing world, Freiburg, Germany, pp. 107-112, Fakultät für Forst- und Umweltwissenschaften der Universität Freiburg Forstliche Versuchs- und Forschungsanstalt Baden-Württemberg

Pouta E (2005) Sensitivity to scope of environmental regulation in contingent valuation of forest cutting practices in Finland. For Policy Econ 7(4):539-550

Prem J (2010) Reporting on the pan-European qualitative indicators for sustainable forest management and national implementation commitments of the ministerial conference on protection of forests in Europe: Austria. Tech. rep., UN economic commission for Europe, food and agricultural organization, ministerial conference on the protection of forests in Europe, Geneva

Primmer E (2011) Policy, project and operational networks: channels and conduits for learning in forest biodiversity conservation. For Policy Econ 13(2):132-142 
Puettmann KJ, Coates KD, Messier Ch (2009) A critique of silviculture: managing for complexity. Island Press, Washington, DC

Pulla P, Schuck A, Verkerk PJ, Lasserre B, Marchetti M, Green T (2013) Mapping the distribution of forest ownership in Europe. Technical Report 88, European Forest Institute

Rands MRW, Adams WM, Bennun L, Butchart SHM, Clements A, Coomes D, Entwistle A, Hodge I, Kapos V, Scharlemann JPW, Sutherland WJ, Vira B (2010) Biodiversity Conservation: challenges beyond 2010. Science 329:1298-1303

Rantala T (2008) Discourse on legitimacy of forest and nature conservation policy in Finnish print media: framework for analysis and revised principles of democratic legitimacy. In: Böcher M, Giessen L, Kleinschmit D (eds) Environmental and forest governance. The role of governance and expertise. Proceedings of the international conference. Universitätsverlag Göttingen Göttingen, pp 41-68

Rayner J, Howlett M (2007) The national forest strategy in comparative perspective. For Chron 83(5):651-657

Saarikoski H, Akerman M, Primmer E (2012) The challenge of governance in regional forest planning: an analysis of participatory forest program processes in Finland. Soc Nat Resour 25(7):667-682

Sgobbi A (2010) Environmental policy integration and the nation state: what can we learn from current practices? In: Goria A, Sgobbi A, von Homeyer I (eds) Governance for the environment. A comparative analysis of environmental policy integration. The fondazione eni enrico mattei (FEEM) series on economics, the environment and sustainable development. Edward Elgar, Cheltenham, UK, Northhampton, MA, pp 9-41

Schanz H, Ottitsch A (2004) Netherlands: Forest policy paragon or NFP failure? In: David Humphreys (ed) Forests for the future. National forest programmes in Europe. Country and regional reports from COST Action E19, pp 193-206

Schanz H (2002) National forest programmes as discursive institutions. For Policy Econ 4(4):269-279

Schmitz F (2010) Reporting on the pan-European qualitative indicators for sustainable forest management and national implementation commitments of the ministerial conference on protection of forests in Europe: Germany. Tech. rep., UN economic commission for Europe, food and agricultural organization, ministerial conference on the protection of forests in Europe, Geneva

Secco L, Da Re R, Gatto P, Tassa DT (2011a) How to measure governance in forestry: key dimensions and indicators from emerging economic mechanisms. Allg For und Jagdztg 182(5-6):69-82

Secco L, Pettenella D, Gatto P (2011b) Forestry governance and collective learning process in Italy: likelihood or utopia? For Policy Econ 13(2):104-112

Serbruyns I, Luyssaert S (2006) Acceptance of sticks, carrots and sermons as policy instruments for directing private forest management. For Policy Econ 9(3):285-296

UNECE-FAO (2000) Forest resources of Europe, CIS, North America, Australia, Japan and New Zealand. Geneva timber and forest study papers 17, United Nations economic commission for Europe, food and agriculture organization of the United Nations

UNECE/FAO, MCPFE and CEPF (2007) Private forest ownership in Europe. Enquiry issued by the United Nations economic commission for europe (UNECE), the food and agricultural organization of the United Nations (FAO), the ministerial conference on the protection of forest $s$ in Europe (MCPFE) and the confederation of European forest owners (CEPF). http://www.unece.org/fileadmin/DAM/timber/ country-info/PFO/UNECE_Enquiry_Private_Forest_Ownership_Handout.pdf. Accessed Mar 2014

Van Gossum P, De Maeyer W (2006) Performance of forest groups in achieving multifunctional forestry in Flanders. Small-Scale For Econ Manag Policy 5(1):19-36

Van Herzele A, Van Gossum P (2009) Owner-specific factors associated with conversion activity in secondary pine plantations. For Policy Econ 11:230-236

Van Herzele A, Aarts N (2013) "My forest, my kingdom"-Self-referentiality as a strategy in the case of small forest owners coping with government regulations. Policy Sci 46(1):63-81

Vandekerkhove K, De Keersmaeker L, Walleyn R, Köhler F, Crevecoeur L, Govaere L, Thomaes A, Verheyen K (2011) Reappearance of old-growth elements in lowland woodlands in northern Belgium: do the associated species follow? Silva Fenn 45(5):909-935

Veenman S, Liefferink D, Arts B (2009) A short history of Dutch forest policy: the 'de-institutionalisation' of a policy arrangement. For Policy Econ 11(3):202-208

Veltheim T (2010) Reporting on the pan-European qualitative indicators for sustainable forest management and national implementation commitments of the ministerial conference on protection of forests in Europe: Finland. Tech. rep., UN economic commission for Europe, food and agricultural organization, ministerial conference on the protection of forests in Europe, Geneva

Venzi L (2008) Outlines of forest policy in Italy: Past experienes and recent developments. In: Cesaro L, Gatto P, Pettenella. D (eds) The multifunctional role of forests-policies, methods and case studies. EFI Proceedings 55, European Forest Institute, Joensuu, pp 39-45 
Voitleithner J (2004) Austria: In the initial stage of a forest dialogue. In: David Humphreys (ed) Forests for the future. National forest programmes in Europe. Country and regional reports from COST Action E19, pp 63-73

Von Arb C, Zimmermann W (2004) Federalism. A characteristic element of swiss forest policy. Institute for human-environment systems department of environmental sciences. Swiss Federal Institute of Technology, ETH Zurich

Vuletić D, Ištok I, Paladinić E (2008) The national forestry policy and strategy—Process or static document? 10th international symposium on legal aspects of European forest sustainable development, Sarajevo, Bosnia and Herzegovina, May 7-9

Weiland S (2010) Sustainability transitions in transition countries: forest policy reforms in South-eastern Europe. Environ Policy Gov 20(6):397-407

Weiland S (2012) Reflexive governance: a way forward? In: Hogl K, Kvarda E, Nordbeck R, Pregernig M (eds) Environmental Governance. The challenge of legitimacy and effectiveness. Edward Elgar, Cheltenham, pp 178-195

Weiss G (1998) Evaluation of mountain forest policy in Austria. Publication series of the institute of forest sector policy and economics 35, Institute of forest sector policy and economics, Vienna, pp 107-136

Weiss G (2004) The political practice of mountain forest restoration-comparing restoration concepts in four European countries. For Ecol Manag 195(1-2):1-13

Winkel G, Sotirov M (2011) An obituary for national forest programmes? Analyzing and learning from the strategic use of "new modes of governance" in Germany and Bulgaria. For Policy Econ 13(2):143-154

Winkel G, Sotirov M (2014) Whose integration is this? European forest policy between the gospel of coordination, institutional competition, and a new spirit of integration. Environ Plan C 32, doi:10.1068/ c1356j

Zimmermann W, Zingerli C (2004) Optimising sustainable forest management. In: David Humphreys (ed) Forests for the future. National forest programmes in Europe. Country and regional reports from COST Action E19, pp 277-293

Zingerli C, Bisang K, Zimmermann W (2004) Nationale forstpolitische Programme: kontext, Anforderungen und das Beispiel "Waldprogramm Schweiz", Forstwissenschaftliche Beiträge 32. ETHZ, Zürich 